\title{
Glacial erosion and bedrock properties in NW Scotland: abrasion and plucking, hardness and joint spacing
}

\author{
Maarten Krabbendam ${ }^{a, *}$ and Neil F. Glasser ${ }^{b}$ \\ ${ }^{a}$ British Geological Survey, Murchison House, West Mains road, Edinburgh, Scotland, UK \\ ${ }^{b}$ Institute of Geography and Earth Sciences, Aberystwyth University, Aberystwyth, Wales, UK \\ * Corresponding author. Tel: ++44 131650256 ; E-mail: mkrab@bgs.ac.uk
}

\begin{abstract}
Subglacial erosion beneath glaciers occurs predominantly by abrasion and plucking, producing distinct erosional forms. The controls on the relative importance of abrasion vs. plucking are poorly understood. On the one hand, glacial conditions that favour or suppress cavity formation (ice velocity, ice thickness, and water pressure) are thought to favour plucking or abrasion, respectively. Conversely, bedrock properties are also known to control landforms, but this has rarely been analysed quantitatively. In this study we compare landforms and bedrock properties of sandstone and quartzite at the bed of a palaeo-ice stream near Ullapool in NW Scotland. The boundary between the rock types is at right angles to the westward palaeo-ice flow, and palaeoglacial conditions on both rock types were similar. We report quantitative parameters for bedrock properties (Schmidt hammer hardness and joint spacing) and use morphometric parameters to analyse the landforms. Torridon sandstone is soft but thick-bedded and with a wide joint spacing. Erosional bedforms include roche moutonnées with smoothed tops and concave stoss sides, whalebacks, and elongate $\mathrm{p}$-forms, indicating a high proportion of abrasion over plucking. Cambrian quartzite is hard but thin-bedded with narrow joint spacing. Erosional landforms are angular to subangular with abundant plucked lee faces, suggesting a high proportion of plucking over abrasion. Hardness and joint spacing thus exert a strong control on subglacial erosional landforms and the mechanisms that formed them. Thus glacial conditions (ice velocity, ice thickness) can only be inferred from glacial erosional landforms if the effects of bedrock properties of the substrate are considered.
\end{abstract}

Keywords: glacial erosion; bedrock; abrasion; plucking; whaleback 


\section{Introduction}

Abrasion and plucking are generally regarded as the dominant erosion mechanisms at the base of glaciers and ice sheets (e.g., Glasser and Bennett, 2004). Glacial abrasion is the surface wear achieved by individual clasts contained within ice or by subglacial sediment sliding over bedrock (Cuffey and Alley, 1996; Hindmarsh, 1996a, b, 1999). Abrasion can involve polishing by siltsize $(<0.01 \mathrm{~m})$ material; scratching, producing grooves, and striae; and the removal of small rock fragments by larger clasts (Hallet, 1979; Iverson, 1991a; Hindmarsh, 1996a). On the grain scale, abrasion can crush individual grains, it can remove grains from adjacent ones, or it can remove multigrain fragments. In contrast, plucking (or quarrying) involves the removal of large fragments; it does not require basal debris but, instead, produces it. The two erosion processes each produce distinct landforms that, after deglaciation, can be easily recognised in the field. Glacial striae, smoothed bedforms such as whalebacks, and elongate $p$-forms are formed by abrasion; whilst quarried or plucked lee-side faces are formed by plucking (e.g., Glasser and Warren, 1990; Sugden et al., 1992; Benn and Evans, 1998; Glasser et al., 1998).

The controls on the relative importance of abrasion vs. plucking are, however, less clear (e.g., Briner and Swanson, 1998). Some authors have highlighted the importance of glacial controls such as ice thickness, ice velocity, and water pressure. Plucking requires that a cavity opens between the glacier and its bed (bed separation), normally in the lee-side of an obstruction. Glacial conditions that are regarded to favour such cavity formation (and hence plucking) are thought to include thin, fast moving (sliding) ice or ice that is subjected to high and fluctuating water pressure. Conversely, glacial conditions such as thick, slow moving, or highly plastic ice are seen to suppress cavity formation and hence plucking, and therefore favour (e.g., Sharp et al., 1989; Glasser and Warren, 1990; Iverson, 1991b; Evans, 1996; Hallet, 1996; Glasser and Bennett, 2004).

Consequently, in deglaciated areas, landform analysis has been used to infer local palaeoglacial conditions such as ice thickness and velocity (Sharp et al., 1989; Evans, 1996; Glasser and Bennett, 2004; Roberts and Long, 2005).

In contrast, other studies have shown a relationship between bedrock lithology and subglacial erosion mechanisms (Glasser et al., 1998; Phillips et al., 2010). Subglacial experiments have shown a clear relationship between rock hardness and subglacial abrasion rates (Boulton, 1979). Equally, numerous studies suggest a strong link between the presence of preexisting mechanical discontinuities (bedding and joints) and plucking (e.g., Gordon, 1981; Rastas and Seppälä, 1981; Rea, 1994; Glasser et al., 1998). Dühnforth et al., (2010) showed that within one rock type (granodiorite) that underwent valley glaciation in Yosemite, areas of close joint spacing experienced faster, deeper glacial erosion than areas of wide joint spacing; and they attributed this to enhanced plucking in areas of close joint spacing. Hardness and joint density are therefore expected to provide strong controls on the mode of erosion (i.e., abrasion vs. plucking). Some studies have also shown that the final products of glacial erosion of bedrock surfaces vary with the degree of preglacial weathering (Lindström, 1988; Olvmo et al., 1999; Johansson et al., 2001a, b; 
Olvmo and Johansson, 2002); in effect this means that the bedrock properties in the top few metres can be different than the bulk bedrock below.

The relative importance of abrasion and plucking are thus dependent on very different factors. To better understand the effect of different controls on subglacial erosion mechanisms requires an area where the role of lithology can be isolated. Glasser et al. (1998) studied the detail of small-scale landforms on different bedrock (psammite, schist, marble), formed under uniform glacial conditions. Sharp et al. (1989) studied a single bedrock landform (composed of ignimbrite) that showed different glacial conditions during different glaciations. However, these and similar studies did not provide quantitative analyses of bedrock properties so that the precise role played by bedrock properties remains elusive.

In this paper we test the hypothesis that, under uniform glacial conditions, bedrock properties exert a strong control on the shape of erosional landforms and, by implication, the subglacial erosion mechanisms that created the landforms. We analyse both the bedrock properties and the landforms in a quantitative or semiquantitative manner and suggest a relatively fast 'reconnaissance type' method to achieve this.

\section{Study area}

The study area is located just north of the village of Ullapool on the NW coast of Scotland (Figs. 1, 2). The area contains two contrasting bedrock types, sandstone and quartzite, with their boundary at high angles to palaeo-ice flow at the base of a palaeo-ice stream. Because the palaeo-ice stream flowed across two lithologies in close proximity, we can be confident that palaeoglacial conditions on either side of the lithological boundary were identical.

\subsection{Palaeoglacial setting}

Northern Scotland was repeatedly glaciated by Pleistocene ice sheets, with the Last Glacial Maximum (LGM) culminating between c. 30 and 20 ka (Late Devensian; e.g., Bradwell et al., 2008a; Hubbard et al., 2009; Scourse et al., 2009). The study area was deglaciated at c. 14-13 ka (Bradwell et al., 2008b; Stoker et al., 2009). The study area occurs in the centre of a palaeo-ice stream (Fig. 1) that joined with other ice streams to become the larger Minch palaeo-ice stream offshore (Stoker and Bradwell, 2005; Bradwell et al., 2008c). Ice flow within the ice stream was topographically constrained between two mountain massifs to the north and south (900-100 m above sea level), resulting in westward ice flow across the study area. Warm-based westward ice flow is corroborated by glacial striae across the study area (Fig. 2), the occurrence of a field of E-W oriented bedrock megagrooves just east of the study area, and streamlined landforms offshore to the west (Bradwell et al., 2008c; Stoker et al., 2009). Ice thickness was at least 700 m (Stone et al., 1998; Ballantyne et al., 1998) but possibly greater (Bradwell and Krabbendam, 2003; Mathers et al., 2010).

\subsection{Bedrock geology setting}


Cambrian quartzite occurs in the east (up-ice) and Torridon sandstone in the west (down-ice) (Krabbendam and Bradwell, 2010). The Torridon sandstone strata dip c. $10^{\circ}$ to the east (Figs. 2, 3). A low angle unconformity, which dips $12-15^{\circ}$ to the east, forms a sharp boundary between the sandstone below and the overlying quartzite. The quartzite occurs at slightly higher ground (200-250 $\mathrm{m}$ ) than the Torridon sandstone (from sea level to c. $200 \mathrm{~m}$ ). The c. 1000-Ma-old Torridon sandstone is a very thick and remarkably uniform sequence of coarse, red, thick-bedded sandstone with subsidiary layers of pebble conglomerate and locally thin layers of siltstone. The sandstone is arkosic, comprising quartz and feldspar grains in a matrix of clay and hematite (e.g., Stewart, 2002). The Cambrian quartzite comprises two members: the Basal Quartzite member and the Pipe Rock member, each 80-120 m thick. In this study, only Basal Quartzite was analysed, but the results are also expected to be valid for the Pipe Rock member, which is more widespread elsewhere in the area. In the study area, beds dips $12-18^{\circ}$ to the E or ESE (i.e. up-ice). The quartzite comprises mainly quartz, with 5-10\% feldspar grains, and with the basal part more feldspathic that higher units. The grains are tightly packed, with very little matrix (McKie, 1990; Prigmore and Rushton, 1999; British Geological Survey, 2008).

\section{Bedrock properties and subglacial erosion mechanisms}

An important issue is which bedrock property is relevant to which erosion mechanism (Augustinus, 1991). In contrast to hill slope processes, glacial valley widening and fluvial erosional processes (e.g., Selby, 1982; Augustinus, 1992; Sklar and Dietrich, 2001; Brook et al., 2004; Moore et al., 2009), the relevant rock properties for subglacial erosion are not well known (e.g., Haynes, 1968; Gordon, 1981).

For abrasion, relevant bedrock properties would be rock hardness of the bed (Boulton, 1979); relative rock hardness between basal debris particles and the bed (Hallet, 1979; Iverson, 1991a) and, when abrasion involves removal of multigrain fragments, fracture toughness or tensile strength of the bed (Iverson, 1991a). Sklar and Dietrich (2001) showed experimentally that (fluvial) abrasion resistance is dependent on absolute hardness of the bed, as well as relative clast-to-bed hardness. They showed a good correlation between fluvial abrasion resistance and tensile strength for a wide range of rock types. In this study, Schmidt hammer rebound values were used as a semiquantitative proxy for abrasion resistance. Over a range of rock types, Schmidt hammer rebound values correlate well with tensile strength, uniaxial compressive strength, and abrasion hardness (Deere and Miller, 1966; Augustinus, 1991; Aydin and Basu, 2005). The Schmidt hammer test is an efficient, nondestructive method that can be performed quickly in the field on a large number of sample sites.

Concerning plucking, unjointed bedrock may possibly fracture subglacially if differential stresses on a rock step are very high (e.g., Hallet, 1996), but these seem to be exceptional circumstances. Joints represent such significant mechanical weaknesses compared to unfractured rock that the occurrence of joints effectively controls whether or not plucking occurs (Mathes, 1930; Rea and Whalley, 1996). This is borne out by a number of field studies describing links between 
joints and plucking (e.g., Mathes, 1930; Rastas and Seppällä, 1981, Gordon, 1981, Sugden et al., 1992; Rea, 1994; Dühnforth et al., 2010). We note here that joints are amongst the most common geological structures on Earth. They are ubiquitous in well-stratified rocks in nonglaciated and glaciated regions alike and they are predominantly caused by non-glacial processes such as tectonic stresses, sedimentary loading, erosive unloading, and cooling (e.g., Jahns, 1943; Davis and Reynolds, 1996; Rogers and Engelder, 2004; Peacock, 2004). Consequently, we assume that the joints in the study areas are pre-glacial (e.g., Laubach and Diaz-Tushman, 2009).

\section{Methods}

\subsection{Landform analysis}

'Roche moutonnée' and 'whaleback' are only two terms for a range of possible bedrock landforms produced by subglacial erosion. Here, we attempt a quantitative analysis of subglacially eroded bedrock landforms. The along-ice profile of landforms (parallel to palaeo-ice flow) was traced from digital photos taken at right angles to ice flow. Three parameters, all normalised, can be derived from these profiles (Fig. 4):

(i) The curvature of the landform, normalised against its thickness. This is here taken as $\boldsymbol{r} / \mathbf{h}$, where $\boldsymbol{h}$ is the height of the landform measured normal to bedding, and $\boldsymbol{r}$ is the radius of the largest circle that fits the sharpest curvature of the profile (Fig. 4A).

For the following two parameters, we assume that plucking creates an approximately rectangular profile on the lee side (this is justified as joints and bedding make approximately right angles, and all plucked faces are at approximately right angles to bedding); whilst abrasion will tend to modify this angular profile to a smoother profile, possibly approaching a segment of an ellipsoid.

(ii) Deviation from a rectangular profile in terms of area (Fig. 4B). $\boldsymbol{A}_{\mathbf{1}}$ is the area of the hypothetical rectangle defined along the bedding planes, constrained by the tangent on the top of the rectangle and its front; $\boldsymbol{A}_{\boldsymbol{e r}}$ is that part of the rectangle that has been eroded. $\boldsymbol{A}_{\boldsymbol{e r}} / \boldsymbol{A}_{\mathbf{1}}$ thus provides a measure of the amount of modification by abrasion of the original rectangular profile;

(iii) The deviation of the rectangle in terms of changes of the profile length (Fig. 4C). This method is similar to the 'tape measure' method used by Kirkbride (2005) and Kirkbride and Bell (2010) to quantify edge rounding by weathering. Kirkbride (2005) assumed that edge rounding by weathering results in symmetric curvature and ideally approaches a segment of a circle. This is not appropriate in this situation, as abrasion will result in an asymmetric profile. Instead, we assume that abrasion will work toward an ellipsoidal profile. We here define the change in length $\Delta L$ as $\left(L_{1}-L_{2}\right) /\left(L_{1}\right.$ $L_{\text {ellipse), where }} L_{1}=\mathbf{a}+\mathbf{b}$, the sides of the rectangle, $L_{2}$ is the length of the real profile as seen in the landforms, and $\boldsymbol{L}_{\text {ellipse }}$ is one-quarter the circumference of an ellipse defined by the axes $\boldsymbol{a}$ and $\boldsymbol{b}$. Thus, if the landform profile approaches a rectangle, $\boldsymbol{\Delta L}$ is close to zero; if it approaches an ellipsoid, $\Delta L$ will move toward 1.

We note that the landforms have been subjected to post-glacial weathering, which may lead to minor modification of the profile since deglaciation: this aspect will be discussed in section 5.1. The quantitative comparison of landforms was applied to outcrops on Beinn Giubhais within the 
altitude range of $180-220 \mathrm{~m}$ (Fig. 2). Individual landforms were numbered to allow crossreferencing between the tables and the profiles. All grid references are British National Grid (BNG).

\subsection{Bedrock properties: hardness and joint spacing}

Schmidt hammer measurements were taken on fresh, striated, bedrock surfaces. All measurements were taken more than $20 \mathrm{~cm}$ away from joints and more than $1 \mathrm{~m}$ away from edges to minimise any edge effects (e.g., Viles et al., 2011). As the presence of lichen significantly lowers the Schmidt hammer values, all surfaces were polished prior to measurement to remove lichen.

For our joint spacing analysis, we first measured joint spacing and orientation on a (subhorizontal) bedding plane to establish the orientation of the dominant joint sets, using a geological compass ('area method'; see for instance Davis and Reynolds, 1996). Joint spacing was subsequently measured along transects of $10 \mathrm{~m}$ or longer of continuous cliff exposures at approximate right angles to the dominant joint sets ('line method'; Davis and Reynolds, 1996). Only open joints were measured: although cemented joints (veins) were noted, these rarely appeared to be continuous or to represent mechanical weaknesses. Bedding thickness was measured on subvertical exposures with a height range of 3-100 $\mathrm{m}$. The definition of a bedding plane as a mechanical discontinuity is somewhat subjective. Here, we measured only those bedding planes that either coincide with a joint (bedding plane joints) or contain a significant concentration of mica or clay minerals, and hence represent a clear mechanical weakness.

\section{Results}

\subsection{Weathering of bedrock}

Post-glacial weathering of bedrock potentially affects both bedrock properties and landforms, and the degree of weathering needs to be considered when interpreting the results of our analyses. Subaerial weathering of quartzite proceeds exceedingly slowly, because its dominant minerals and its silica cement are chemically stable under mid-latitude atmospheric conditions. This is corroborated by the excellent preservation of glacial striae on this lithology throughout the region (e.g., Lawson, 1996). The absence or rarity of scree or loose blocks below the lee-side rock steps indicates that modification of the quartzite landforms by periglacial frost weathering and post-glacial slope processes has been absent or negligible (Fig. 5). Note that, larger quartzite cliffs (> $20 \mathrm{~m}$ high) throughout the region are characterised by more intense slope processes, commonly fed by blockfields on summit areas (e.g., Ballantyne, 1995).

In contrast, the Torridon sandstone is more susceptible to subaerial weathering, mainly because its matrix is rich in clay and hematite. The hardness of Torridon sandstone is reduced significantly by subaerial weathering, especially at elevations > $500 \mathrm{~m}$ (McCarroll et al., 1995). Outcrops of Torridon sandstone generally have a 'creased' appearance as a result of enhanced weathering along joints and bedding planes (Fig. 6; see also Bradwell and Krabbendam, 2003; McCarroll et al., 1995). In a few localities (Fig. 6A), the original striated surface can be found adjacent to a more weathered surface. This shows that post-glacial processes have removed 
between 5 and $10 \mathrm{~cm}$ of material, with deepest weathering occurring along joints. This is consistent with the joint depth measurements between 1.5 and $10 \mathrm{~cm}$ of McCarroll et al. (1995). Kirkbride and Bell (2010) measured edge roundness radii between 4 and $8 \mathrm{~cm}$ of Torridon sandstone boulders for moraines and rockfalls of Younger Dryas and late Devensian ('Wester Ross Readvance'; c. 13 ka) age. In one locality in our study area, a plucked face of a roche moutonnée occurs adjacent to a whaleback (Fig. 6B, background). This shows that post-glacial weathering has not significantly affected the overall shape of the landform. Overall, post-glacial surface weathering of Torridon sandstone surfaces has probably not exceeded $\sim 10 \mathrm{~cm}$. The Torridon sandstone landforms are typically $>1 \mathrm{~m}$ in height, so that weathering introduces an 'error' of $<10 \%$ to the morphometric analyses.

\subsection{Glacial erosional landforms}

Glacial erosional landforms on Cambrian quartzite are angular to subangular. Outcrops typically consist of a gentle east-dipping stoss side developed approximately along a bedding plane and a steep, west-dipping subvertical lee-side developed along joint planes (Figs. 5, 7). Outcrops thus form 'roches moutonnées' commonly approaching ideal rectangular prisms, with fairly sharp crests (Figs. 5A, B). Individual prisms are 5-10 $\mathrm{m}$ long and 1-3 $\mathrm{m}$ high, but 'nested' prisms can occur and form c. 10-15 m high stepped rock faces (Fig. 5B). The stoss sides are typically striated; locally, crescentic fractures occur on the stoss side close $(<1 \mathrm{~m})$ to the crests. P-forms are very rare. Striated surfaces are common, but probably involved minimal erosion: cross-cutting striae are relatively widespread in the region (see Lawson, 1996) and show that the last striation event did not abrade sufficient material to remove the evidence of the first one (see also Sharp et al., 1989). Farther north in Assynt, where the Pipe Rock member is more widespread (Peach et al., 1907; British Geological Survey, 2007), Skolithos pipe-shaped trace fossils still form 'dimples' on striated surfaces, constraining abrasion to a few millimetres. Subaerial surface weathering of quartzite proceeds exceedingly slowly, and the preservation potential of striae is much higher than that of any other rocks in the region (e.g., Lawson, 1996). The abundance of striae, therefore, provides no indication of intensity of abrasion; rather, it indicates a lack of post-glacial weathering.

Overall, outcrops of Cambrian quartzite are dominated by landforms associated with glacial plucking, whilst (micro)landforms related to glacial abrasion involved only a minor amount of erosion.

Glacial erosional landforms on Torridon sandstone are typically subrounded roches moutonnées, transitional to whalebacks. On Beinn Giubhais, the landforms are typically 7-30 m long and 2-5 m high (Figs. 6B, C). On Meall nan Clachan (Fig. 2, top), however, some very elongate whalebacks are up to $100 \mathrm{~m}$ long and 2-5 m high (Fig. 6D). Edges of roches moutonnées are smoothly curved (Figs. 6, 7), even taking into account c. 5-10 cm of post-glacial weathering (see above). Numerous roches moutonnées also show a dip, or a shallow concave curve, on the stoss side (Fig. 7), a feature not observed on quartzite landforms. Elongate p-forms, parallel to palaeo-ice flow, are very common (Fig. 6C). Very well preserved, highly elongate p-forms occur just above sea level near Keanchulish, associated with striae up to $2 \mathrm{~m}$ long (Bradwell, 2010). Surfaces little affected by post-glacial 
weathering (recently exhumed from beneath till or peat in, for instance, road cuttings) are ubiquitously smooth and rounded and show abundant deep striae.

There is evidence of lee-side plucking (Fig. 6B, background), but most roches moutonnées are highly elongate, and the longitudinal (down-ice) spacing of plucked faces is high (> 50-200 m) (see also Bradwell et al., 2008c, their Fig. 7). Apparently, plucking only occurred along widely spaced 'master' joints. Torridon sandstone occurs down-ice from Cambrian quartzite (Fig. 2), and small $(<0.1 \mathrm{~m})$ erratics of Cambrian quartzite are abundant on outcrops of Torridon sandstone. Therefore, the sandstone has been abraded by basal debris that was substantially harder than itself, making abrasion very efficient (e.g., Boulton, 1979). Overall, glacial erosional landforms on Torridon sandstone are dominated by abrasion, with plucking evident only on widely spaced master joints.

\subsection{Quantitative landform analysis}

The results of the quantitative landform analysis are presented in Table 1 and Fig. 8. The average normalised radius $(\boldsymbol{r} / \mathbf{h})$ of quartzite landforms is 0.145 , whilst that of sandstone whalebacks is 0.41 . Sandstone landforms are thus more smoothly curved than quartzite landforms. The change in profile area $\left(\boldsymbol{A}_{\text {er }} / \boldsymbol{A}_{1}\right)$ and the change in profile length $(\Delta \mathrm{L})$ are both consistently larger for sandstone landforms than for quartzite landforms. The frontal parts of some sandstone whalebacks approach an ideal ellipse, for example landform T124 (Fig. 8). The values for Torridon sandstone landforms are more variable and show a wider standard deviation for the normalised radius and the change in profile area (Table 1). This reflects a higher variability in landform profile, as seen in Fig. 7. Landforms T116F and T116B diverge strongly from the ideal ellipse and have a complex shape with small normalised radii, presumably as they were formed by a mix of plucking and abrasion. Overall, sandstone landforms are smoother and more ellipsoid in profile than quartzite landforms, which are more angular.

\subsection{Bedrock properties}

Results of the bedrock property analyses are presented in Table 2 and Fig. 9. The Cambrian quartzite is the harder rock (Schmidt hammer $R$-values of $\sim 60$ ). The median bed thickness is $0.16 \mathrm{~m}$ and joint spacing is $0.29 \mathrm{~m}$. The average rectangular 'block' delineated by two bedding planes and four joint surfaces is $\sim 0.013 \mathrm{~m}^{3}$. The Torridon sandstone is the softer rock (Schmidt hammer $R$ values of $\sim 45$ ). The median bed thickness is $1.4 \mathrm{~m}$, joint spacing $2.6 \mathrm{~m}$, and the average block volume is $\sim 9 \mathrm{~m}^{3}$, almost two orders of magnitude larger than the block volume of quartzite.

\section{Discussion and conclusions}

Glacial erosional bedrock landforms show a marked contrast in morphology on different lithologies in an area where palaeoglaciol conditions of warm-based palaeo-ice flow were areally constant. The differences in morphology can be related to the subglacial erosional mechanisms that formed them (abrasion or plucking) (e.g., Evans, 1996; Benn and Evans, 1998; Glasser and Bennett, 2004). The differences in lithology have been quantified by measuring appropriate bedrock properties. Summarising, hard rocks with dense joint spacing (e.g., Cambrian quartzite) appear to be 
preferentially eroded by plucking, whilst relatively soft rocks with wide joint spacing (e.g., Torridon sandstone) erode preferentially by abrasion. We note that we do not have a quantitative control on the erosion rate by plucking. This would require a detailed cosmogenic exposure age study (e.g. Briner and Swanson, 1998; Duhnforth et al., 2010), but even in these cases, plucking erosion rates are minimal values. Similar conclusions concerning the relative importance of abrasion and plucking were drawn by Hancock et al. (1998) and Whipple et al. (2000) for fluvial erosion on different lithologies.

The bedrock properties of the two lithologies analysed in this study are plotted against each other in Fig. 9. In this graph, fields can be defined in which certain erosion mechanisms are dominant under given constant glacial conditions. Thus, a 'plucking-dominant field' can be defined for rocks that are hard but have a dense joint spacing, whilst an 'abrasion-dominant field' is expected for softer rocks with wider joint spacing. We suggest that these two fields are separated by a field in which plucking and abrasion are of broadly equal dominance. The fields can be used to predict the preferential erosion mechanism on different lithologies, which can be quantitatively tested in future studies.

In addition, overall glacial erosion resistance can be predicted, with low erosion resistance close to the 'apex' and increasing erosion resistance away from the 'apex'. Schematic 'erosion resistance' contours can be added (Fig. 9), although the shape of these contours (straight, convex, or concave) cannot be constrained at present, with a study of only two rock types. We have added bedrock properties of some other lithologies from the literature to Fig. 9. In addition, we have shown the range of Schmidt hammer rebound values for a range of rock types (Fig. 9, right-hand side) as reported by Deere and Miller (1966). This allows us to explore some further implications:

(i) A lithology with a particular hardness can have highly variable joint spacing, for instance in the vicinity of tectonic faults. Beacom et al. (2001) showed that, in the Lewisian Gneiss in Scotland, joint spacing can vary by 1-2 orders of magnitude. The effect of local variations in joint spacing is well illustrated by studies on glacial erosion of granitic rocks in Yosemite. Mathes (1930) showed qualitatively that densely jointed granite in Yosemite was more susceptible to plucking than less jointed granite; this was confirmed quantitatively by Dühnforth et al. (2010) using cosmogenic nuclide exposure dating techniques. Thus, the presence of densely spaced joints moves the granite from one erosion-mode field into another, as well as making it more susceptible to erosion. The implication is that a particular rock type cannot be predicted to be more susceptible to subglacial erosion than another (cf. Phillips et al., 2010), without taking local variations in joint spacing into account.

(ii) Igneous and metaigneous rocks such as granites and ortho gneisses plot well away from the apex (e.g., Lewisian Gneiss and Yosemite granite; Fig. 9). Such rocks are hard and commonly have a wide joint spacing. In this field that abrasion and plucking are equally favoured. Notably, such rocks are typically found in landscapes of aerial scour, and a typical mixture of whalebacks and roche moutonnées have been reported in such landscapes (Gordon, 1981; Rea and Evans, 1996; 
Roberts and Long, 2005). In this field, the dominant erosion mechanism is probably largely determined by glacial conditions such as ice velocity and thickness, in the manner suggested by Glasser and Warren (1990) and others. However, we suspect that for rocks that plot close to one or the other axis it may not be valid to deduce glacial conditions from landforms alone.

(iii) Rocktypes plotting close to the apex would include friable shales, certain chalks, and deeply weathered bedrock, transitional to regolith. It is likely that the distinction between plucking and abrasion becomes blurred in this region. Few studies on subglacial landforms developed on such rocks have been performed (Lindström, 1988). This is probably because these rocks are also highly susceptible to post-glacial erosion, so that few fresh landforms are preserved in the geological record, and because glacial erosion may be so efficient that debris production is very high, resulting in subglacial deposition of till (e.g., Phillips et al., 2010).

(iv)) Abrasion is commonly regarded as being less efficient than plucking (Briner and Swanson, 1998; Dühnforth et al., 2010). Typically, this conclusion is based on roche moutonnée-like landforms, where it can be demonstrated that abrasion on the top and stoss side was quantitatively less than erosion by plucking from the lee side (e.g., Jahns, 1943; Briner and Swanson, 1998). However, this point has only been demonstrated for hard rocks such as granite (Jahns, 1943; Dühnforth et al., 2010) and gabbro (Briner and Swanson, 1998). We suggest that this rule cannot be applied as the general case but is, in fact, dependent on rock properties. In a relatively soft rock with wide joint spacing, such as the Torridon sandstone in this study, we suggest that abrasion is as efficient (if not more so) as plucking.

Our overall conclusion is that palaeoglacial conditions can only be inferred from glacial erosional landforms in a particular deglaciated area if the effects of different bedrock properties of the substrate on erosion mechanisms are considered fully.

\section{Acknowledgements}

Tom Bradwell is thanked for early discussions. Two anonymous reviewers are thanked. $M$ Krabbendam published with the permission of the Director of the British Geological Survey (Natural Environment Research Council). 


\section{References}

Augustinus, P.C., 1991. Rock resistance to erosion: some further considerations. Earth Surface Processes and Landforms 16, 563-569.

Augustinus, P.C., 1992. The influence of rock mass strength on glacial valley cross-profile morphometry: a case study from the Southern Alps, New Zealand. Earth Surface Processes and Landforms 17, 39- 51.

Aydin, A., Basu, A., 2005. The Schmidt hammer in rock material characterization. Engineering Geology 81, 1-14.

Ballantyne, C.K., 1995. Periglacial features in Assynt and Coigach. In: Lawson, T.J. (Ed), The Quaternary of Assynt and Coigach: Field Guide. Quaternary Research Association, Cambridge, UK, pp. 47-60.

Ballantyne, C.K., McCarroll, D., Nesje, A., Dahl, S.O., Stone, J.O., 1998. The last ice sheet in northwest Scotland; reconstruction and implications. Quaternary Science Reviews 17, 1149-1184.

Beacom, L.E., Holdsworth, R.E., McCaffrey, K.J.W., Anderson, T.B., 2001. A quantitative study of the influence of pre-existing compositional and fabric heterogeneities upon fracture-zone development during basement reactivation. In: Holdsworth, R.E., Strachan, R.A., Macgloughlin, J.F., Knipe, R J. (Eds), The Nature and Significance of Fault Zone Weakening. Geological Society Special Publication 186, London, pp. 195-211.

Benn, D.I., Evans, D.J.A., 1998. Glaciers and Glaciation. Arnold, London, pp. 734.

Boulton, G.S., 1979. Processes of glacier erosion on different substrata. Journal of Glaciology 23, 15-38.

Bradwell, T., Krabbendam, M., 2003. Stac Pollaidh: A Late Devensian Nunatak? Quaternary Newsletters 100, 19-25.

Bradwell, T.B., Stoker, M.S., Golledge, N.R., Wilson, C.K., Merritt, J.W., Long, D., Everest, J.D., Hestvik, O.B., Stevenson, A.G., Hubbard, A.L., Finlayson, A.G., Mathers, H.E., 2008a. The northern sector of the last British Ice Sheet: maximum extent and demise. Earth Science Reviews 88, 207-226.

Bradwell, T., Fabel, D., Stoker, M.S., Mathers, H., McHargue, L., Howe, J., 2008b. Ice caps existed throughout the lateglacial interstadial in northern Scotland. Journal of Quaternary Science 23, 401-407.

Bradwell, T., Stoker, M.S., Krabbendam., M., 2008c. Megagrooves and streamlined bedrock in NW Scotland: the role of ice streams in landscape evolution. Geomorphology 97, 135-156.

Bradwell, T., 2010. Keanchulish P-forms. In: Lukas, S. Bradwell, T. (Eds), The Quaternary of Western Sutherland and Adjacent Areas: Field Guide. Quaternary Research Association, London, pp. 119-122.

Briner, J.P., Swanson, T.W., 1998. Using inherited cosmogenic ${ }^{36} \mathrm{Cl}$ to constrain glacial erosion rates of the Cordilleran ice sheet. Geology 26, 3-6.

British Geological Survey, 2007. Assynt. Scotland Special Sheet. Bedrock. 1:50 000 Geology Series. British Geological Survey, Keyworth, Nottingham, UK.

British Geological Survey, 2008. Ullapool. Scotland Sheet 101E. Bedrock. 1:50 000 Series. British Geological Survey, Keyworth, Nottingham, UK. 
Brook, M.A., Kirkbride, M.P., Brock, B.W., 2004. Rock strength and development of glacial valley morphology in the Scottish Highlands and northwest Iceland. Geografiska Annaler 86A, 225234.

Cuffey, K., Alley, R.B., 1996. Is erosion by deforming subglacial sediments significant? (Toward till continuity). Annals of Glaciology 22, 17-24.

Davis, G.H., Reynolds, S.J., 1996. Structural geology of rocks and regions. John Wiley, New York, $776 \mathrm{pp}$.

Deere, D., Miller, R., 1966. Engineering Classification and Index Properties for Intact Rock. Air Force Weapons Laboratory Technical Report, AFWL-TR-65-116, Kirtland Air Force base, New Mexico, 300 pp.

Dühnforth, M., Anderson, R.S., Ward, D., Stock, G., 2010. Bedrock fracture control of glacial erosion processes and rates. Geology 38, 423-426.

Evans, I.S., 1996. Abraded rock landforms (whalebacks) developed under ice streams in mountain areas. Annals of Glaciology 22, 9-16.

Glasser, N.F., Bennett, M.R., 2004. Glacial erosional landforms; origins and significance for palaeoglaciology. Progress in Physical Geography 28, 43-75.

Glasser, N.F., Warren, C.R., 1990. Medium scale landforms of glacial erosion in south Greenland; process and form. Geografiska Annaler 72A, 211-215.

Glasser, N.F., Crawford, K.R., Hambrey, M.J., Bennett, M.R., Huddart, D., 1998. Lithological and structural controls on the surface wear characteristics of glaciated metamorphic bedrock surfaces: Ossian Sarsfjellet, Svalbard. Journal of Geology 106, 319-330.

Gordon, J.E., 1981. Ice-scoured topography and its relationship to bedrock structure and ice movements in parts of northern Scotland and west Greenland. Geografiska Annaler 63A, 5565.

Hallet, B., 1979. A theoretical model of glacial abrasion. Journal of Glaciology 23, 39-50.

Hallet, B., 1996. Glacial quarrying: a simple theoretical model. Annals of Glaciology 22, 1-8.

Hancock, G.S., Anderson, R.S. Whipple, K.X., 1998. Beyond Power: Bedrock River Incision Process and Form. In: Tinkler, K.J. and E. Wohl, E.E. (Eds), Rivers over rock: fluvial processes in Bedrock channels. American Geophysical Union, Washington, pp. 35-60.

Haynes, V.M., 1968. The influence of glacial erosion and rock structure on corries in Scotland Geografiska Annaler 50A, 221-234.

Hindmarsh, R.C.A., 1996a. Sliding of till over bedrock: scratching, polishing, comminution and kinematic-wave theory. Annals of Glaciology 22, 41-47.

Hindmarsh, R.C.A., 1996b. Cavities and the effective pressure between abrading clasts and bedrock. Annals of Glaciology 22, 32-40.

Hindmarsh, R.C.A., 1999. Coupled ice-till dynamics and the seeding of drumlins and bedrock forms. Annals of Glaciology 28, 221-230.

Hubbard, A., Bradwell, T., Golledge, N., Hall, A., Patton, H., Sugden, D., Cooper, R., Stoker, M., 2009. Dynamic cycles, ice streams and their impact on the extent, chronology and deglaciation of the British-Irish ice sheet. Quaternary Science Reviews 28, 759-777. 
Iverson, N.R., 1991a. Morphology of glacial striae: implications for abrasion of glacier beds and fault surfaces. Geological Society of America Bulletin 103, 1308-1316.

Iverson, N.R., 1991b. Potential effects of subglacial water-pressure fluctuations on quarrying. Journal of Glaciology 37, 27-36.

Jahns, R.H., 1943. Sheet structure in granites: its origin and use as a measure of glacial erosion in New England. Journal of Geology 51, 71-98.

Johansson, M., Migon, P., Olvmo, M., 2001a. Development of joint-controlled rock basins in Bohus granite, SW Sweden. Geomorphology 40, 145-161.

Johansson, M., Olvmo, M., Lidmar, B.K., 2001b. Inherited landforms and glacial impact of different palaeosurfaces in southwest Sweden. Geografiska Annaler 83A, 67-89.

Kirkbride, M.P., 2005. Boulder edge-roundness as an indicator of relative age: a Lochnagar case study. Scottish Geographical Journal 121, 215-232.

Kirkbride, M.P., Bell, C.M., 2010. Edge-roundness of boulders of Torridonian Sandstone (northwest Scotland): applications for relative dating and implications for warm and cold climate weathering rates. Boreas 39, 187-198.

Krabbendam, M., Bradwell, T., 2010. The geology and landscape of the Northwest Highlands: an introduction. In: Lukas, S., Bradwell, T. (Eds), The Quaternary of Western Sutherland and adjacent areas: Field Guide. Quaternary Research Association, London, pp. 3-12.

Krabbendam, M., Bradwell, T., in press. Lateral plucking as a mechanism for elongate erosional glacial bedforms: explaining megagrooves in Britain and Canada. Earth Surface Processes and Landforms. DOI: 10.1002/esp.2157.

Laubach, S.E., Diaz-Tushman, K., 2009. Laurentian palaeostress trajectories and ephemeral fracture permeability, Cambrian Eriboll Formation sandstones west of the Moine Thrust Zone, NW Scotland. Journal of the Geological Society 166, 349-362.

Lawson, T.J., 1996. Glacial striae and former ice movement; the evidence from Assynt, Sutherland. Scottish Journal of Geology 32, 59-65.

Lindström, E., 1988. Are roches moutonnées mainly preglacial forms? Geografiska Annaler 70A, 323-331.

Mathers, H., Fabel, D., Bradwell, T., 2010. Polythermal ice in the Assynt Mountains: Ice sheet thickness, deglaciation and differential erosion. In: Lukas, S., Bradwell, T. (Eds), The Quaternary of Western Sutherland and adjacent areas: Field Guide. Quaternary Research Association, London, pp. 169-179.

Mathes, F., 1930. Geologic history of the Yosemite Valley. Geological Survey Professional Paper, 160, US Geological Survey, Washington, 137 pp.

McCarroll, D., Ballantyne, C.K., Nesje, A., Dahl, S.O., 1995. Nunataks of the last ice sheet in Northwest Scotland. Boreas 24, 305-323.

McKie, T., 1990. Tidal and storm influenced sedimentation from a Cambrian transgressive passive margin sequence. Journal of the Geological Society of London 147, 785-794.

Moore, J.R., Sanders, J.W., Dietrich, W.E., Glaser, S.D., 2009. Influence of rock mass strength on the erosion rate of alpine cliffs. Earth Surface Processes and Landforms 34, 1339-1352. 
Olvmo, M., Johansson, M., 2002. The significance of rock structure, lithology and pre-glacial deep weathering for the shape of intermediate-scale glacial erosional landforms. Earth Surface Processes and Landforms 27, 251-268.

Olvmo, M., Lidmar-Bergström, K., Lindberg, G., 1999. The glacial impact on an exhumed subMesozoic etch surface in southwestern Sweden. Annals of Glaciology 28, 153-160.

Peach, B.N., Horne, J., Gunn, W., Clough, C.T., Hinxman, L.W., Teall, J.J.H., 1907. The Geological Structure of the North-West Highlands of Scotland. Memoir of the Geological Survey of Great Britain, HMSO, Glasgow, 668 pp.

Peacock, D.C.P., 2004. Differences between veins and joints using the example of the Jurassic limestones of Somerset In: Cosgrove, J.W. and T. Engelder, T (Eds), The Initiation, Propagation, and Arrest of Joints and Other Fractures. Geological Society Special Publication 231, London, pp. 209-221

Phillips, E., Everest, J., Diaz-Doce, D., 2010. Bedrock controls on subglacial landform distribution and geomorphological processes: Evidence from the Late Devensian Irish Sea Ice Stream. Sedimentary Geology 232, 98-118.

Prigmore, J.K., Rushton, A.W.A., 1999. Scotland: Cambrian and Ordovician of the Hebridean Terrane. In:. Rushton, A.W.A Owen, A.W. Owens R.M. Prigmore J.K. (Eds), British Cambrian to Ordovician Stratigraphy. Geological Conservation Review Series 18. Chapman \& Hall, Peterborough, UK, pp. 295-315.

Rastas, J., Seppälä, M., 1981. Rock jointing and abrasion forms on roches moutonnées, SW Finland. Annals of Glaciology 2, 159-163.

Rea, B.R., 1994. Joint control in the formation of rock steps in the subglacial environment. In: D.A. Robinson, D.A., Williams R.B.G. (Eds), Rock Weathering and Landform Evolution. John Wiley, London, 473-486.

Rea, B.R., Evans, D.J.A., 1996. Landscapes of aerial scouring in NW Scotland. Scottish Geographical Magazine 112, 47-50.

Rea, B.R., Whalley, W.B., 1996. The role of bedrock topography, structure, ice dynamics and preglacial weathering in controlling subglacial erosion beneath a high-latitude, maritime ice field. Annals of Glaciology 22, 121-125.

Roberts, D.H., Long, A.J., 2005. Streamlined bedrock terrain and fast ice flow, Jakobshavns Isbrae, West Greenland; implications for ice stream and ice sheet dynamics. Boreas 34, 25-42.

Rogers, C.M., Engelder, T., 2004. The feedback between joint-zone development and downward erosion of regularly spaced canyons in the Navajo Sandstone, Zion National Park, Utah. In: Cosgrove J.W., T. Engelder, T. (Eds), The Initiation, Propagation, and Arrest of Joints and Other Fractures. Geological Society Special Publication 231, London, pp. 49-71

Scourse, J.D., Haapaniemi, A.I., Colmenero-Hidalgo, E., Peck, V.L., Hall, I.R., Austin, W.E.N., Knutz, P.C., Zahn, R., 2009. Growth, dynamics and deglaciation of the last British-Irish ice sheet: the deep-sea ice-rafted detritus record. Quaternary Science Reviews 28, 3066-3084.

Selby, M.J., 1982. Controls on the stability and inclinations of hillslopes formed on hard rock. Earth Surface Processes and Landforms 7, 449-467. 
Sharp, M., Dowdeswell, J.A., Gemmell, J.C., 1989. Reconstructing past glacier dynamics and erosion from glacial geomorphic evidence; Snowdon, North Wales. Journal of Quaternary Science 4, 115-130.

Sklar, L.S., Dietrich, W.E., 2001. Sediment and rock strength controls on river incision into bedrock. Geology 29, 1087-1090.

Stewart, A.D., 2002. The later Proterozoic Torridonian Rocks of Scotland: Their Sedimentology, Geochemistry and Origin. Geological Society Memoir, 24, The Geological Society, London, $130 \mathrm{pp}$. .

Stoker, M.S., Bradwell, T., 2005. The Minch palaeo-ice-stream: NW sector of the British-Irish Ice Sheet. Journal of the Geological Society of London 162, 425-428.

Stoker, M.S., Bradwell, T., Howe, J.A., Wilkinson, I.P., McIntyre, K., 2009. Lateglacial ice-cap dynamics in NW Scotland: evidence from the fjords of the Summer Isles region. Quaternary Science Reviews 28, 3161-3184.

Stone, J.O., Ballantyne, C.K., Fifield, L.K., 1998. Exposure dating and validation of periglacial weathering limits, northwest Scotland. Geology 26, 587-590.

Sugden, D.E., Glasser, N.F., Clapperton, C.M., 1992. Evolution of large roches moutonnées. Geografiska Annaler 74A, 253-264.

Viles, H., Goudie, A., Grab, S., Lalley, J., 2011. The use of the Schmidt Hammer and Equotip for rock hardness assessment in geomorphology and heritage science: a comparative analysis. Earth Surface Processes and Landforms 36, 320-333.

Whipple, K.X., Hancock, G.S., Anderson, R.S., 2000. River incision into bedrock; mechanics and relative efficacy of plucking, abrasion, and cavitation. Geological Society of America Bulletin 112, 490-503. 


\section{Figures}
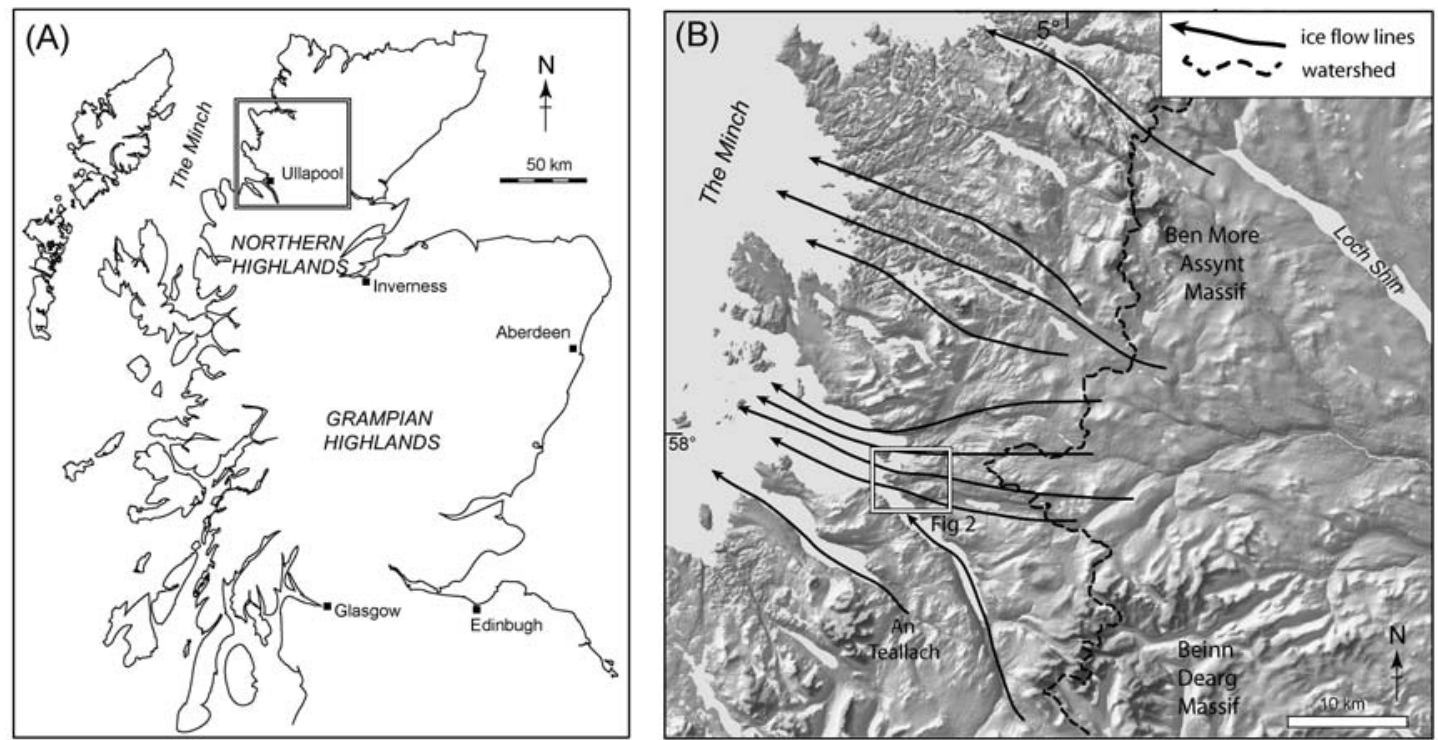

Fig. 1. (A) General location map of Scotland. (B) Palaeoglacial setting of study area within the northwest Highlands of Scotland. Hill shaded relief derived from NEXTMap Britain elevation data from Intermap Technologies 


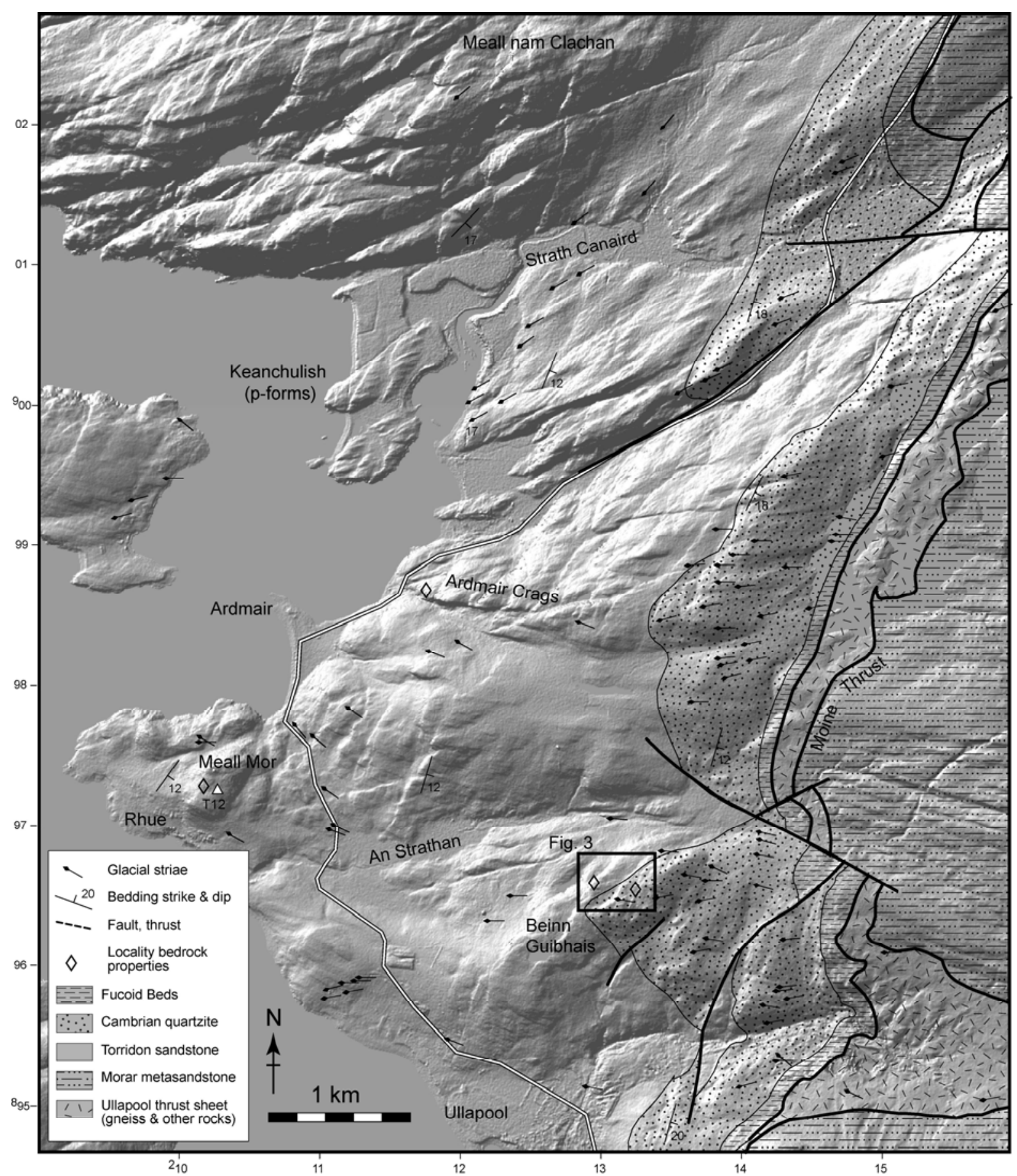

Fig. 2. NEXTMap shaded relief image of the Ullapool - Ardmair area, overlain by simplified bedrock geology, after British Geological Survey (2008). Ice flow was from east to west, at right angles to most geological boundaries. Striae taken from original (1886 - 1888) Geological Survey 1:10,560 clean copies in the British Geological Survey archive. Localities where detailed bedrock properties were measured in this paper are indicated by diamonds. Box shows position of Fig. 3. NEXTMap Britain elevation data from Intermap Technologies. Hill-shading effect generated by illumination from the NW. 




Fig. 3. Orthorectified aerial photo of Beinn Guibhais area (see box on Fig. 2), showing locations of landforms analysed in this study area (triangles). All landforms except T12 (see Fig. 2) occur within this area. Boundary between sandstone and quartzite is indicated. 


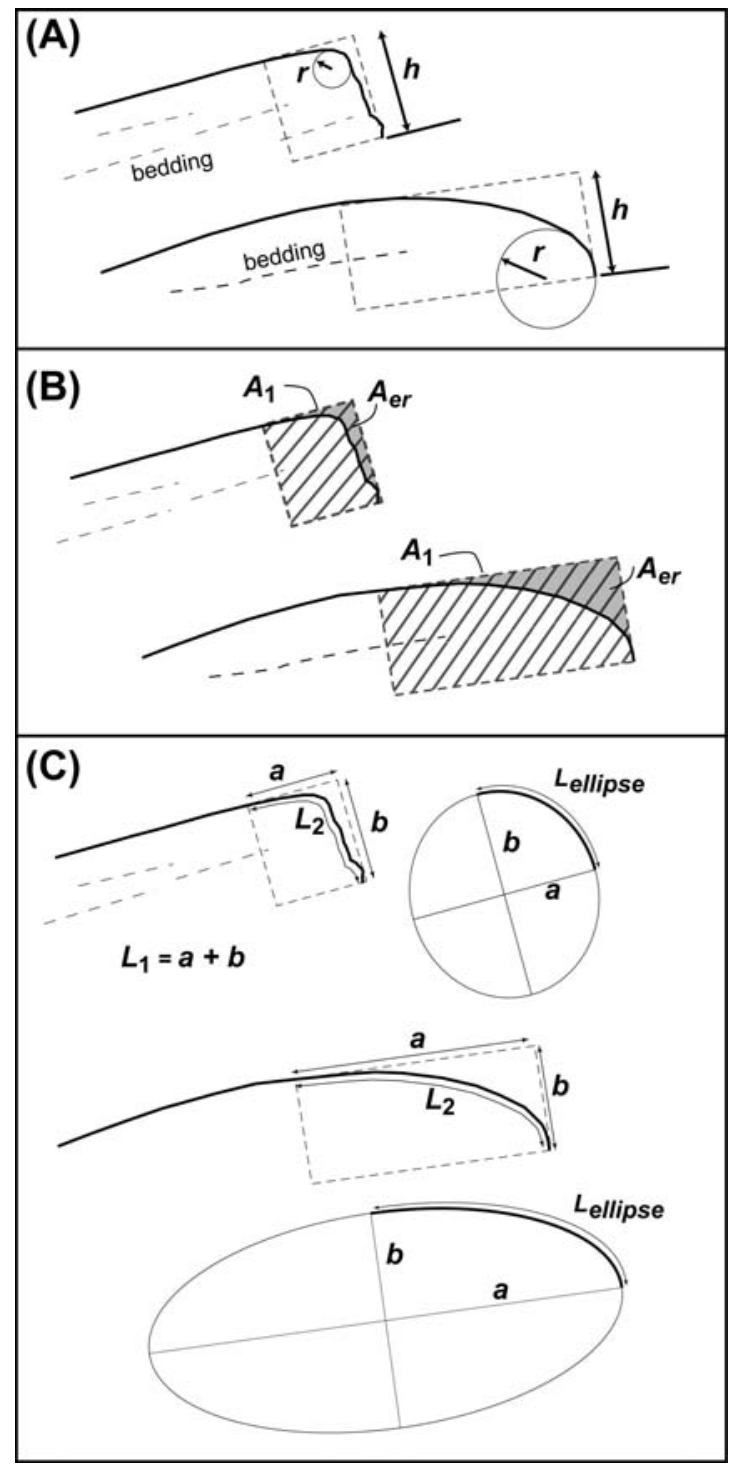

Fig. 4. Parameters for morphometric analysis of landforms, illustrated for a quartzite 'roche moutonnée' (left) and a sandstone 'whaleback' (right). Profiles were traced from digital photos of landforms, taken at right angles to palaeo-ice flow. (A) Radius of curvature $r$ and height of landform $\boldsymbol{h}$, measured normal to bedding. (B) Change in area of profile: $\boldsymbol{A}_{\mathbf{1}}$ is area of rectangle defining frontal part of landform (hatched), $\boldsymbol{A}_{\text {er }}$ is that part of the rectangle that has eroded (grey). (C) Change in length of perimeter of profile. $L_{1}=\boldsymbol{a}+\boldsymbol{b}$, the sides of the rectangle; $L_{2}$ is the length of the profile as measured from the landform; $L_{\text {ellipse }}$ is one-quarter of the perimeter of the ellipse defined by axes $\boldsymbol{a}$ and $\boldsymbol{b}$. For further explanation see text.

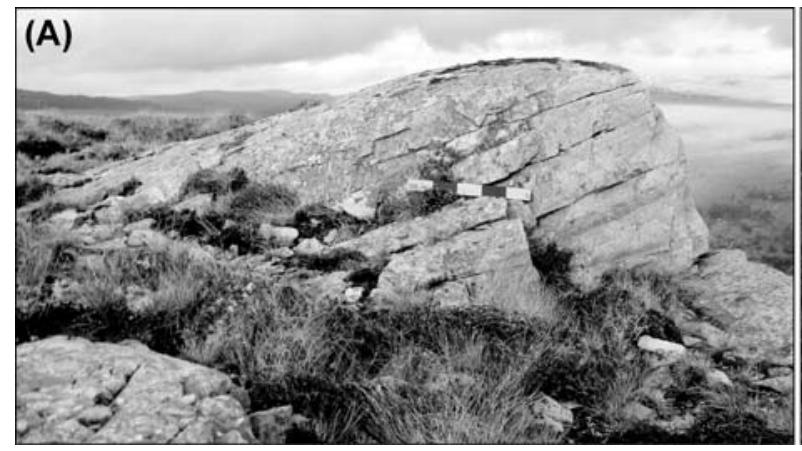

(B)



Fig. 5. Landforms on Cambrian quartzite, Beinn Giubhais. British national grid (BNG): NH 131 965. All viewed to the south; palaeo-ice flow left to right. (A) Subangular landform, with moderately curved edge. Scale ruler is $50 \mathrm{~cm}$ long. (B) Nested set of angular landforms forming rock step. Note the absence of scree, which indicates that block removal took place under glacial conditions and not post-glacial frost shattering. Width of view c. $80 \mathrm{~m}$. 

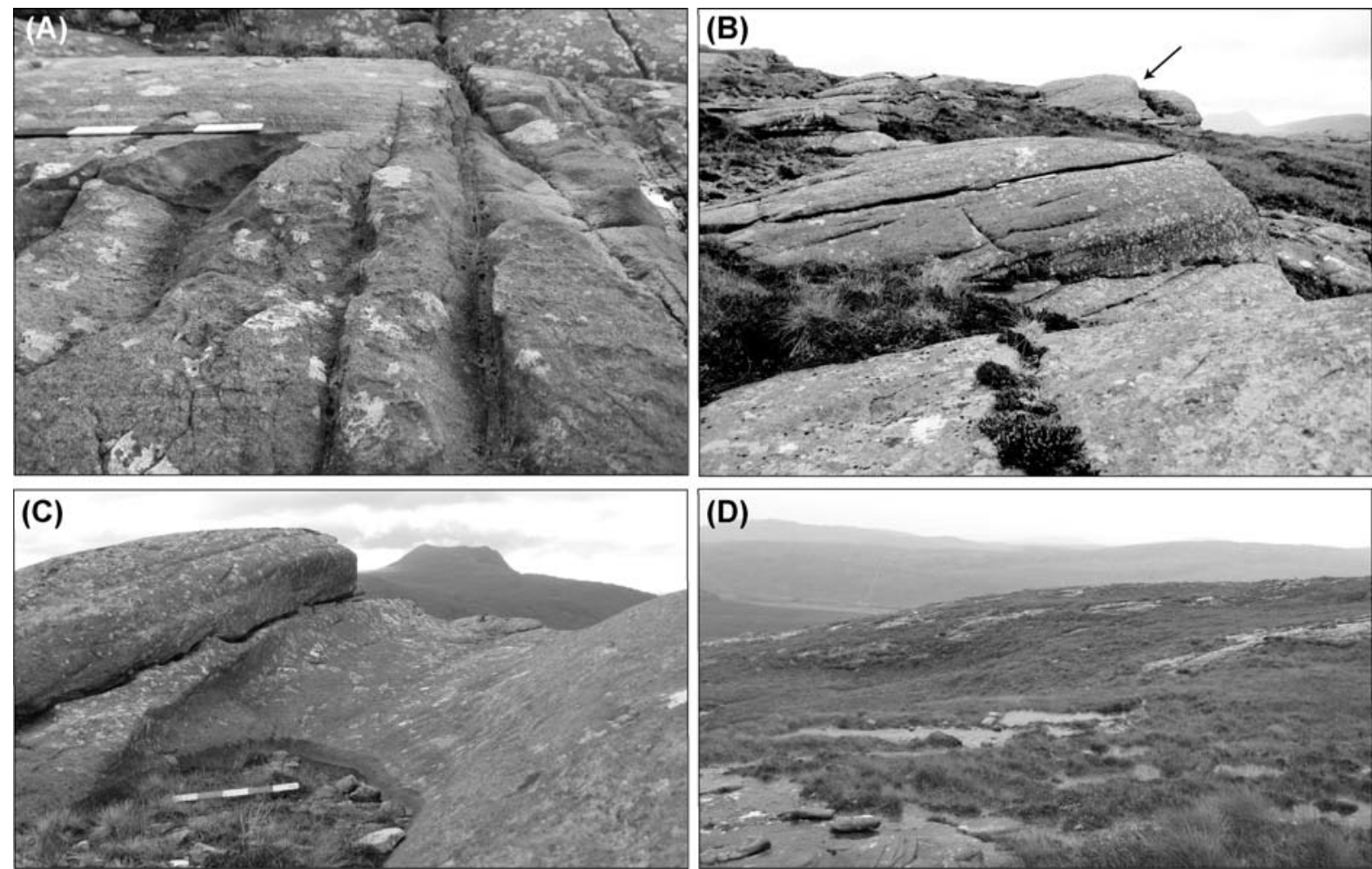

Fig. 6. Landforms on Torridon sandstone. All viewed to south; ice flow from left to right (oblique for (C)). Scale ruler is $50 \mathrm{~cm}$. All photos on Beinn Giubhais, except (D): Meall nan Clachan. (A) Post-glacial weathering of Torridon sandstone surfaces. Above the ruler, the surface is striated with east-west trending striae; below and to the right of the ruler the surface has been weathered since deglaciation. Weathering is deepest along joints. BNG: NH 129 966. (B) Steep, smooth whaleback in the foreground. In the background a roche moutonnée with a plucked face (arrowed). BNG: NH 129 966. (C) Smooth roche moutonnée with 'half-pipe' p-form. BNG: NH 129 965. (D) Elongate whaleback measuring c. 100 m. BNG: NC 133027.

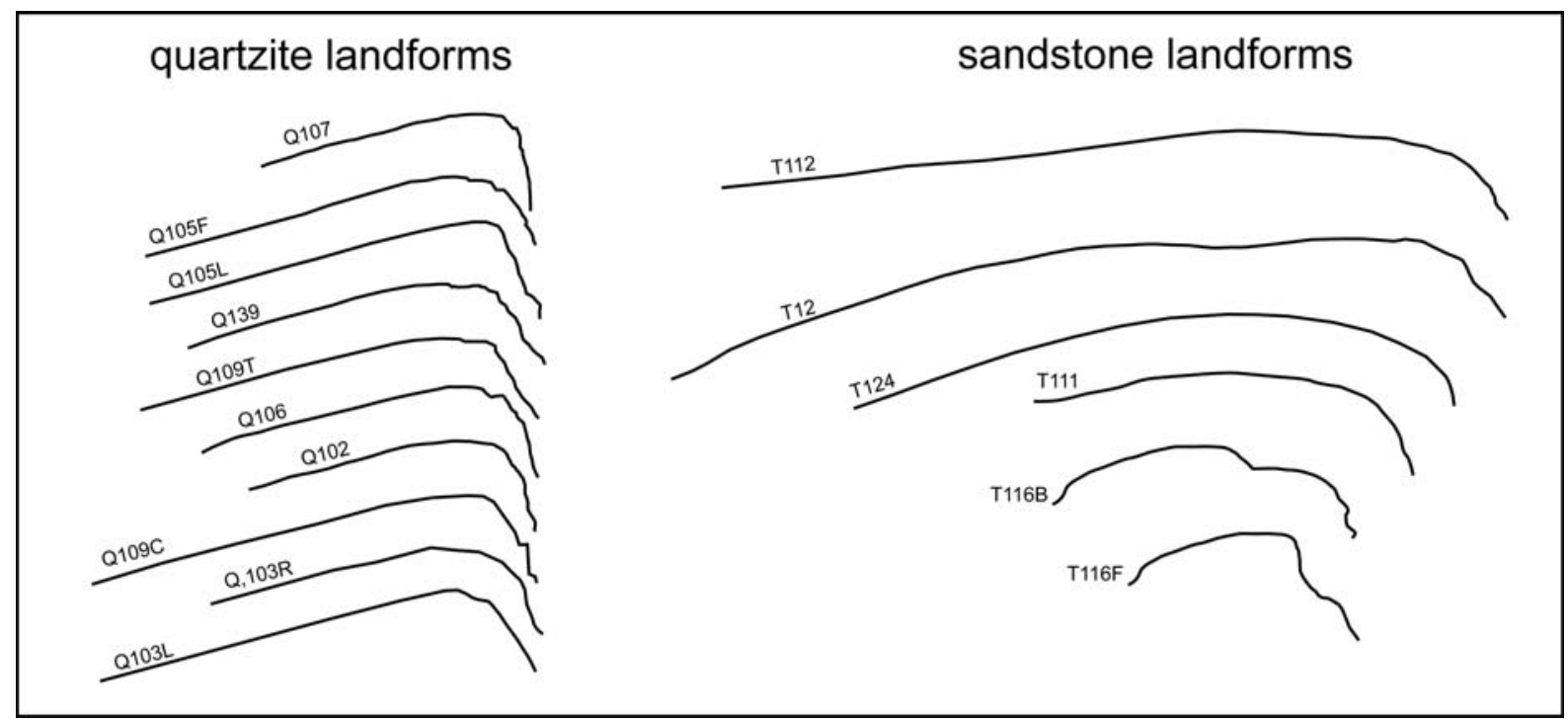

Fig. 7. Profiles of landforms on quartzite and sandstone. Ice flow left to right. Profiles have been normalized and are shown at equal height. True height varies between 1 and $5 \mathrm{~m}$, see Figs 5, 6. Numbers refer to individual landforms, shown in Fig. 3. 


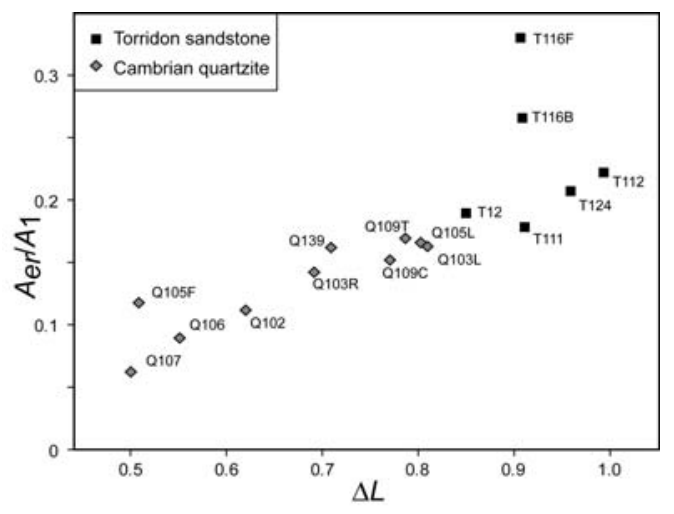

Fig. 8. Results of morphometric analysis of landforms on Cambrian quartzite and Torridon sandstone. $\boldsymbol{A}_{\mathrm{er}} / \boldsymbol{A}_{\mathbf{1}}$ : change in surface area of profile; $\boldsymbol{\Delta L}$ : change in profile length; $\boldsymbol{r} / \boldsymbol{h}$ : normalised radius of curvature. See text and Fig. 4 for further explanation. Numbers refer to individual landforms shown in Fig. 3.
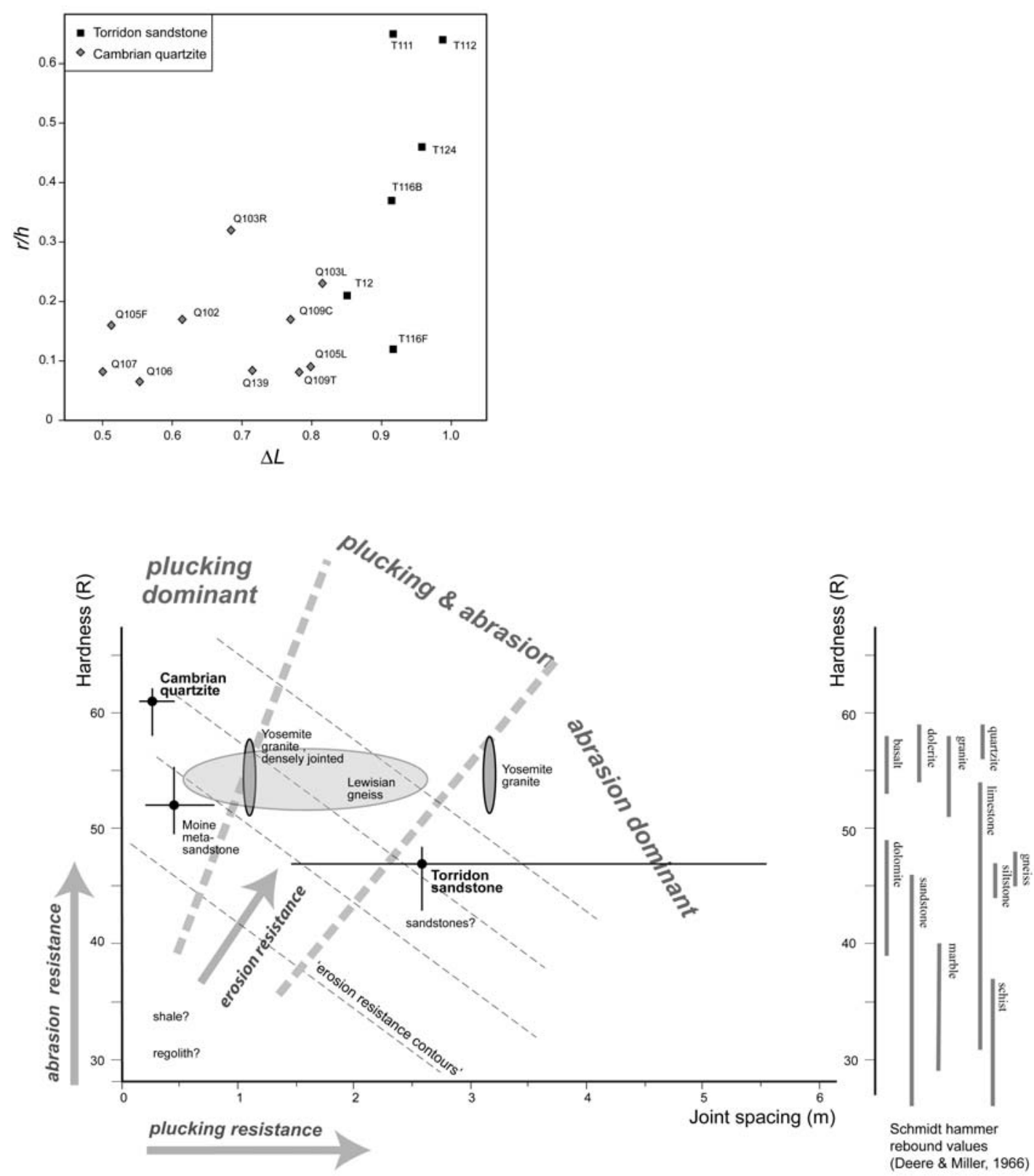

Fig. 9. Schematic diagram showing relation between hardness, joint spacing, and dominant erosional processes under assumed constant subglacial conditions. Hardness and joint spacing of lithologies analysed in this study (Cambrian quartzite and Torridon sandstone) are shown. Error bars show interquartile ranges. Yosemite granite: joint spacing after Dühnforth et al., (2010); hardness from Deere and Miller (1966). Moine metasandstone data from Krabbendam and Bradwell (in press). Lewisian gneiss data from unpublished data from author. On right hand side: Schmidt hammer hardness for different lithologies after Deere and Miller (1966). The figure shows the general relationship of joint spacing and bedrock hardness and dominant erosion mechanism under constant glacial conditions. See text for full explanation. 